\title{
Time to chart Europe's future
}

Britain is once more the black sheep of Europe, after another row about agricultural policy, but the event is also an opportunity. Somebody should seize it.

This is turning out to be a bad year for the European Community. After what should have been a cheerful twenty-fifth anniversary (see Nature 25 March, p.278) that had most member governments asking "What have we done wrong?", a quarrel redolent of the turbulent 1960 s has broken out between Britain (assisted by Denmark and Greece) and the six other states. The issue is that which has dogged the Community since it began - the price to be fixed for agricultural products in the year already under way. British unwillingness to agree to price increases exceeding 10 per cent had been well advertised in advance, as had the British government's insistence that this year, as in the past two, it should pay less towards the common budget than the rules of the Community require. With other things on its mind (see below), the British government obviously failed to sense that if it stuck to its position, the convention that any member state can veto any proposal would not save it from being voted down. This, in the event, is what happened. In the next few weeks, the member states will be looking for some way of picking up the pieces.

That will not be easy. Ever since it joined the European Community in 1972, the British government has been grumbling about the common agricultural policy, in effect a device for paying European farmers well so as to produce more food than Europe can consume. For much of that time, the British have been chipping away at the policy, and not always in the most highminded spirit. Only a few weeks ago, a British agriculture minister was boasting to the House of Commons how he and his colleagues had managed to dip British hands into the pork barrel, winning more than a quarter of a new subsidy on suckling cows and virtually the whole of the novel subsidy for sheep. The difficulty, which successive British governments have been slow to recognize, is that the common agricultural policy, the constant but of their complaints against the Community, is as much a political necessity for other member states as is the right to veto any proposal judged to touch a vital issue is for Britain. These are eminently circumstances that call for compromise and selfrestraint. Pretending that the truth is otherwise will lead nowhere. The ideal is that the common agricultural policy should wither, perhaps because it is overtaken by farmers' recognition that, in the modern industrial state that Europe seeks to be, there are more interesting and profitable things to do than till the land. What the Community should be looking for, in the rowdy weeks that lie ahead, is some means of making that ambition come nearer.

The difficulties are nicely illustrated by the grand French plan to do something within the Community about the commercial challenge from Japan in the electronics industry (see page 257). The obvious objection to the French plan for the revivification of the French electronics industry is that it is a national plan, and one based on the substantial investment of government funds. Even if the enthusiasts for the scheme were able to recruit the funds they seek, and if their use of them were wise, the result would merely be to make the electronics industry in the rest of Europe even more hard-pressed than at present. The result of that would be to renew the clamour that national governments should do even more than at present to help their own domestic manufacturers, perhaps by putting more business their way. The end result would be a system not very different from that now embodied in the common agricultural policy - a European electronics industry protected from the outside world by high tariff barriers, selling its products at prices that are too high and competing fiercely with itself. That is not a recipe for meeting the challenge from outside but, rather, a recipe for continued failure. The government of France seems not to appreciate that the Japanese success in electronics has been founded on an accurate appraisal of the international market, and that the only effective counter - admittedly only a first step - is to make the European market in electronic products thoroughly international. So will the French, and their Community partners, give up their present policies of channelling public contracts towards their domestic companies? Not, the guess is, without a struggle.

That, however, is precisely the struggle on which the British government, blackballed last week in Brussels, should now embark. The fact that the electronics industry in Europe is closely linked with defence, specifically exempted by the Treaty of Rome from the rigours of the open market, is not the stumbling block it seems but rather the opposite. It is foolish that half of the ten governments in the European Community should be spending large sums of money on the solution of essentially similar problems, hoping to recover part of the cost by sales of advanced military equipment overseas. Why should not each of them spend less on research and development, selling the products to each other in the first place? The result could well be that member states' strategic independence would be compromised, but is it seriously suggested that the constant rows within the European Community imply that one day it may be necessary for the members to attack each other? The pretence of military independence in which the member governments of the European Community at present luxuriate is belied by what their electors know - that culturally the Community is already so much of a piece that unscrambling it would be literally unfeasible. The advantage to the British government of taking the initiative on this issue of electronics and, where necessary, defence, is that it could throw those who baited it last week onto the defensive, yet hope to emerge with a prize to offer its own people that would be at least as valuable as the cost of the agricultural policy.

\section{Rules for limited war}

\section{The Falkland Islands conflict marks a step towards the automation of conventional war.}

The politics of the Falkland Islands war is outside Nature's bailiwick, but the technology is not. For what is happening now in the South Atlantic is probably a foretaste of what may happen all too often in decades to come. First, it is a limited war in which neither side seeks the comprehensive capitulation of its adversary. Second, it is a high-technology war in which the combatants are equipped with virtually automatic weapons developed against the possibility of conventional conflict in Europe, but now being used in a mercifully remote part of the world, one so distant that other states are unlikely to be drawn in. What lessons, spine-chilling and otherwise, can be drawn from what is now going on?

That limited wars, out of fashion since the eighteenth century, are still feasible should not be a surprise. The Yom Kippur war of 1973 was limited in the sense that the Israeli objective was the capture of a tract of territory, the Sinai desert up to the Suez 